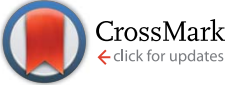

Cite this: RSC Adv., 2017, 7, 13696

\title{
Novel cytotoxic steroidal saponins from the roots of Liriope muscari (Decne.) L.H. Bailey $\dagger$
}

\author{
Yan Wu, ${ }^{a}$ Xian-Min Wang, ${ }^{a}$ Su-Xia Bi, ${ }^{a}$ Wen Zhang, ${ }^{b}$ Rui-Ming Li, ${ }^{\text {ab }}$ Rui-Jing Wang, ${ }^{b}$ \\ Bo-Yang $\mathrm{Yu}^{\star a}$ and Jin Qi ${ }^{\star a}$
}

Ten new steroidal saponins (1-10) and three known steroidal saponins (11-13) were isolated from a $70 \%$ $\mathrm{EtOH}$ extract of the roots of Liriope muscari (Decne.) L. H. Bailey. Their structures were determined by analyses of infrared, nuclear magnetic resonance and mass spectroscopic data. These compounds exhibited different levels of cytotoxic activity against MDA-MB-435, 95D, HepG2, HeLa, MCF-7 and A549 cell lines in an in vitro bioassay. The structure-activity relationship of these related compounds was also investigated.

Received 30th October 2016

Accepted 17th February 2017

DOI: $10.1039 / \mathrm{c} 6 \mathrm{ra26031d}$

rsc.li/rsc-advances

Although some phytochemical investigations of L. muscari have been reported,,$^{7,30-35}$ the steroidal components of the herb are still not fully elucidated. To promote a better understanding of the steroidal components of $L$. muscari and enable further screening for potentially useful bioactive ingredients, a 70\% EtOH extract of $L$. muscari was studied. As a result, 10 novel steroidal saponins (1-10) were identified, and three known steroidal saponins (11-13) were also obtained. The structures of these compounds were elucidated based on infrared (IR), nuclear magnetic resonance (NMR) and mass spectroscopic data. The cytotoxic activities of the compounds were evaluated using the 3-(4,5-dimethylthiazol-2-yl)-2,5-diphenyltetrazolium bromide (MTT) assay. The isolation, structural characterization and cytotoxic activities of the compounds are described in detail in this article. Furthermore, the structure-activity relationship of these related compounds is also discussed to better interpret the activities of these steroidal compounds.

that they exhibit diverse biological properties, including anticancer, anti-inflammatory, antimicrobial, insecticidal and molluscicidal activities. ${ }^{16,17}$ Recently, the antitumorigenic properties of steroidal saponins have attracted attention for the development of antitumor therapies. Significant antitumor activities of some steroidal saponins from $L$. muscari have been demonstrated in vitro and in vivo., ${ }^{7,18-27}$ For example, DT-13, a mixture of $25(R / S)$ steroidal saponins isolated from L. muscari, significantly suppresses adhesion and invasion of cancer cells, and has been considered a candidate drug for prevention of cancer metastasis. ${ }^{18-29}$

\footnotetext{
ajiangsu Key Laboratory of TCM Evaluation and Translational Research, China Pharmaceutical University, Nanjing 211198, China. E-mail: boyangyu59@163.com; yaoyuelingxing@163.com; Fax:+86-025-86185158; Tel: +86-025-86185157

${ }^{b}$ Tasly Research Institute, Tianjin Tasly Holding Group Co. Ltd., Tianjin 300410, China

$\dagger$ Electronic supplementary information (ESI) available. See DOI: $10.1039 /$ c6ra26031d
}

\section{Results and discussion}

Compound 1 was obtained as a white amorphous powder and gave a positive Liebermann-Burchard reaction. Its molecular formula was determined as $\mathrm{C}_{44} \mathrm{H}_{70} \mathrm{O}_{18}$ according to HRESIQTOF-MS data $\left(\mathrm{m} / \mathrm{z} 909.4456[\mathrm{M}+\mathrm{Na}]^{+}\right.$, calcd 909.4454). The ${ }^{1} \mathrm{H}$ and ${ }^{13} \mathrm{C}$ spectra of 1 (Tables 1-4) displayed the following characteristic signals: two tertiary methyl groups $\left(\delta_{\mathrm{H}} 1.34, \mathrm{~s} ; \delta_{\mathrm{H}}\right.$ $0.88, \mathrm{~s})$, two secondary methyl groups $\left(\delta_{\mathrm{H}} 1.14, \mathrm{~d}, J=7.0 \mathrm{~Hz} ; \delta_{\mathrm{H}}\right.$ $1.08, \mathrm{~d}, J=7.0 \mathrm{~Hz})$, one quaternary carbon $\left(\delta_{\mathrm{C}} 109.7\right)$ and an olefinic group $\left(\delta_{\mathrm{C}} 139.4\right.$ and $124.7 ; \delta_{\mathrm{H}} 5.52$, brs, $\left.1 \mathrm{H}\right)$. Moreover, the ${ }^{1} \mathrm{H}$-NMR spectrum showed three anomeric proton signals $\left[\delta_{\mathrm{H}} 5.04(1 \mathrm{H}, \mathrm{d}, J=7.7 \mathrm{~Hz}), 5.52(1 \mathrm{H}, \mathrm{d}, J=7.7 \mathrm{~Hz})\right.$ and $5.29(1 \mathrm{H}$, $\mathrm{d}, J=7.7 \mathrm{~Hz}$ )], giving heteronuclear single quantum correlation (HSQC) correlations with three anomeric carbon signals at $\delta_{\mathrm{C}} 100.1,104.7$ and 105.3, respectively. These observations together with the characteristic absorptions of a 25(S) spiroketal 
Table $1{ }^{13} \mathrm{C}$ NMR data for aglycone moieties of compounds $1-10^{a}\left(\delta\right.$ in ppm, pyridine- $\left.d_{5}\right)$

\begin{tabular}{|c|c|c|c|c|c|c|c|c|c|c|}
\hline Position & 1 & 2 & 3 & 4 & 5 & 6 & 7 & 8 & 9 & 10 \\
\hline 1 & 82.6 & 82.5 & 82.6 & 82.4 & 84.5 & 82.8 & 82.5 & 82.6 & 84.3 & 83.0 \\
\hline 2 & 37.2 & 36.9 & 36.7 & 36.5 & 37.7 & 37.3 & 37.0 & 36.7 & 37.5 & 37.4 \\
\hline 4 & 43.7 & 43.5 & 43.5 & 43.4 & 43.4 & 43.7 & 43.4 & 43.5 & 43.4 & 43.6 \\
\hline 5 & 139.4 & 139.2 & 139.4 & 139.2 & 139.2 & 140.0 & 139.6 & 139.4 & 140.0 & 139.8 \\
\hline 6 & 124.7 & 124.7 & 124.6 & 124.4 & 124.8 & 124.3 & 124.1 & 124.6 & 124.6 & 124.4 \\
\hline 9 & 50.3 & 50.2 & 50.5 & 50.1 & 50.2 & 50.3 & 50.0 & 50.2 & 50.0 & 50.4 \\
\hline 10 & 42.7 & 42.6 & 42.8 & 42.6 & 42.6 & 43.0 & 42.7 & 42.8 & 42.4 & 42.9 \\
\hline 11 & 23.9 & 23.8 & 23.7 & 23.4 & 24.1 & 23.6 & 23.4 & 23.7 & 23.9 & 23.7 \\
\hline 12 & 40.3 & 40.2 & 40.2 & 40.0 & 40.3 & 40.5 & 40.2 & 40.1 & 40.0 & 40.3 \\
\hline 13 & 40.2 & 40.1 & 40.0 & 39.9 & 40.2 & 40.3 & 40.0 & 40.1 & 40.0 & 40.4 \\
\hline 14 & 56.8 & 56.7 & 56.6 & 56.4 & 56.8 & 57.0 & 56.8 & 56.6 & 56.7 & 57.0 \\
\hline 19 & 15.0 & 14.9 & 14.9 & 14.7 & 15.0 & 15.1 & 14.9 & 14.9 & 14.8 & 15.1 \\
\hline 20 & 42.5 & 41.9 & 42.3 & 41.7 & 41.9 & 42.6 & 41.8 & 41.7 & 41.6 & 41.9 \\
\hline 21 & 14.8 & 14.8 & 14.7 & 14.7 & 14.9 & 14.9 & 14.8 & 14.8 & 14.6 & 14.9 \\
\hline 22 & 109.7 & 109.2 & 109.7 & 109.0 & 109.2 & 109.8 & 109.0 & 109.4 & 109.3 & 109.5 \\
\hline 23 & 26.4 & 31.6 & 26.3 & 31.5 & 31.7 & 26.4 & 31.6 & 33.1 & 32.8 & 33.0 \\
\hline 24 & 26.2 & 29.1 & 26.1 & 28.9 & 29.2 & 26.3 & 29.0 & 28.8 & 28.6 & 29.0 \\
\hline 25 & 27.6 & 30.5 & 27.4 & 30.3 & 30.5 & 27.6 & 30.4 & 144.3 & 144.2 & 144.6 \\
\hline 26 & 65.0 & 66.7 & 64.9 & 66.5 & 66.7 & 65.1 & 66.6 & 64.9 & 64.6 & 65.0 \\
\hline 27 & 16.3 & 17.2 & 16.2 & 17.0 & 17.2 & 16.3 & 17.1 & 108.6 & 108.4 & 108.6 \\
\hline
\end{tabular}

${ }^{a} \mathrm{NMR}$ data were measured at $500 \mathrm{MHz}$ for ${ }^{1} \mathrm{H}$ and at $125 \mathrm{MHz}$ for ${ }^{13} \mathrm{C}$ in pyridine- $d_{5}$. Assignments are based on TCOSY, HSQC, and $\mathrm{HMBC}$ experiments.

unit at 987, 920, 896, 848, and $920>896 \mathrm{~cm}^{-1}$ in the IR spectrum and chemical shifts at $\delta_{\mathrm{C}} 26.4$ (C-23), 26.2 (C-24), 27.6 (C-25), and 65.0 (C-26) in the ${ }^{13} \mathrm{C}-\mathrm{NMR}$ spectrum suggested that 1 was a $(25 S)$-spirostanol derivative containing three sugar units. $^{36}$

On the basis of the HSQC and heteronuclear multiple-bond correlation (HMBC) correlations, the aglycone moiety of compound 1 was identified as $(25 S)$-ruscogenin. ${ }^{37}$ The analyses of chemical shifts and coupling constants $(J=7.5-8.0 \mathrm{~Hz})$ obtained from extensive $1 \mathrm{D}$ and 2D NMR experiments allowed the identification of two $\beta$-glucopyranosyl units and one $\beta$ xylopyranosyl unit in $\mathbf{1}$. The sugar residues were further confirmed by co-thin-layer chromatography (co-TLC) with standard sugars after hydrolysis of $\mathbf{1}$, and the D-configurations were confirmed by gas chromatography (GC) of their corresponding trimethylsilylthiazolidine derivatives. This procedure was also applied to the other new compounds (2-10). The sequence of the sugar chain and the glycosidic position of 1 were determined by HMBC, HSQC and total correlation spectroscopy (TOCSY) experiments. The HMBC correlations (Fig. 1) of the anomeric proton signal at $\delta_{\mathrm{H}} 5.52(\mathrm{~d}, J=7.7 \mathrm{~Hz}$, Glu H$1^{\prime \prime}$ ) to $\delta_{\mathrm{C}} 81.6\left(\mathrm{Glu} \mathrm{C}-2^{\prime}\right)$, from $\delta_{\mathrm{H}} 5.29(\mathrm{~d}, J=7.7 \mathrm{~Hz}$, Xyl H-1"' $)$ to $\delta_{\mathrm{C}} 86.0$ (Glu C-3') and from $\delta_{\mathrm{H}} 5.04$ (d, $J=8.0 \mathrm{~Hz}$, Glu H-1 ${ }^{\prime}$ ) to $\delta_{\mathrm{C}} 82.6$ (Agly C-1) proved that the sequence of the sugar chain was Glu- $(1 \rightarrow 2)$-[Xyl- $(1 \rightarrow 3)]-G l u$ and that the glycosidic site was at C-1. Other key HMBC, HSQC and TOCSY correlations are shown in the ESI data. $\dagger$ The structure of compound 1 was therefore assigned as (25S)-ruscogenin-1- $O-\beta$-D-glucopyranosyl- $(1 \rightarrow 2)$-[ $\beta$-D-xylop yranosyl- $(1 \rightarrow 3)]$ - $\beta$-D-glucopyranoside.

The HRESI-QTOF-MS spectrum of compound $2(\mathrm{~m} / \mathrm{z} 909.4454$ $[\mathrm{M}+\mathrm{Na}]^{+}$, calcd 909.4454) supported a molecular formula of $\mathrm{C}_{44} \mathrm{H}_{70} \mathrm{O}_{18}$, the same as compound 1. A detailed analysis of the NMR data of 2 (Tables 1-4) compared to those for 1 showed that 2 contained the same sugar chain at $\mathrm{C}-1$ as compound $\mathbf{1}$. The major difference was that the chemical shifts at $\delta_{\mathrm{C}} 31.58$ (C-23), 29.13 (C-24), 30.47 (C-25) and 66.73 (C-26) in the ${ }^{13} \mathrm{C}-\mathrm{NMR}$ spectrum had lower field resonances than those of $\mathbf{1}$, indicating that the configuration at C-25 was $R$. This result was further confirmed by the characteristic absorptions of a $25(R)$ spiroketal unit at 982 , $921,902,870 \mathrm{~cm}^{-1}$, and $902>921 \mathrm{~cm}^{-1}$ in the IR spectrum. The aglycone moiety of 2 was identified as (25R)-ruscogenin by comparison of spectroscopic data to those reported in the literature. ${ }^{37}$ Compound 2 was therefor assigned as (25R)-ruscogenin1 - $O$ - $\beta$-D-glucopyranosyl- $(1 \rightarrow 2)$-[ $\beta$-D-xylopyranosyl- $(1 \rightarrow 3)]$ - $\beta$-D-glucopyranoside. Key HMBC, HSQC and TOCSY correlations are shown in Fig. 1 and the ESI data. $\dagger$

The molecular formula of compound 3 was determined as $\mathrm{C}_{43} \mathrm{H}_{68} \mathrm{O}_{17}$ from the ion peak $[\mathrm{M}+\mathrm{Na}]^{+}$at $\mathrm{m} / z$ 879.4344 (calcd 879.4349) in the HRESI-QTOF-MS. The IR absorption bands at 3390 and $1072 \mathrm{~cm}^{-1}$ indicated the presence of hydroxyl and $\mathrm{C}-\mathrm{O}$ groups, respectively. Comparison of the NMR data of 3 obtained from 1D and 2D NMR spectra (Tables 1-4) to those of 1 showed that they contained the same aglycone moiety ((25S)-ruscogenin), but differed slightly in the sugar moiety. The major difference 
1

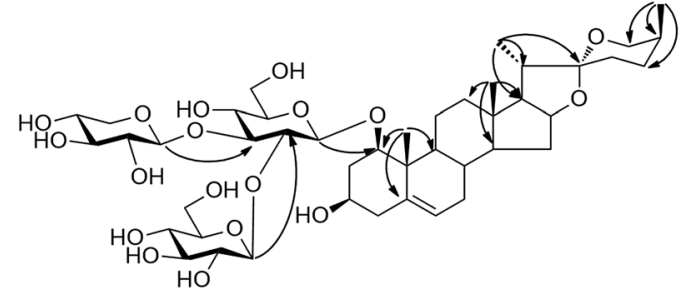

2

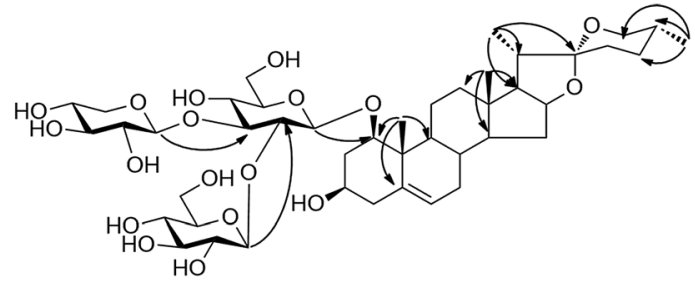

5

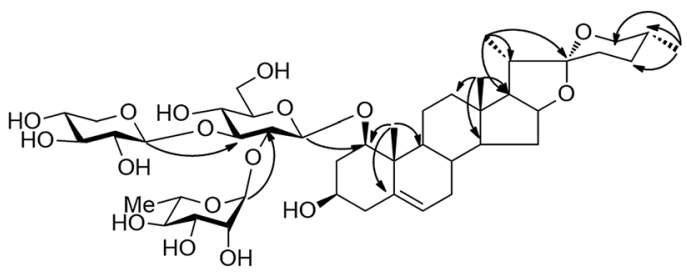

6

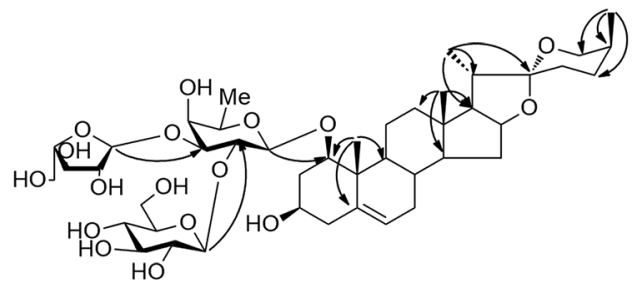

7

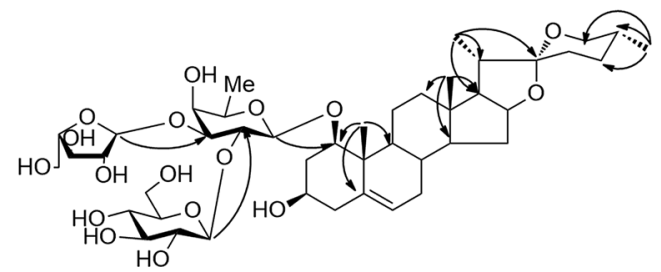

3

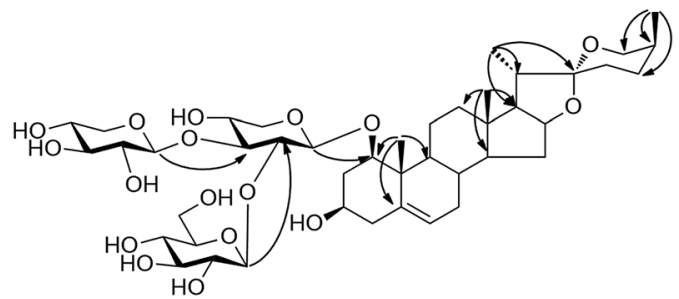

4

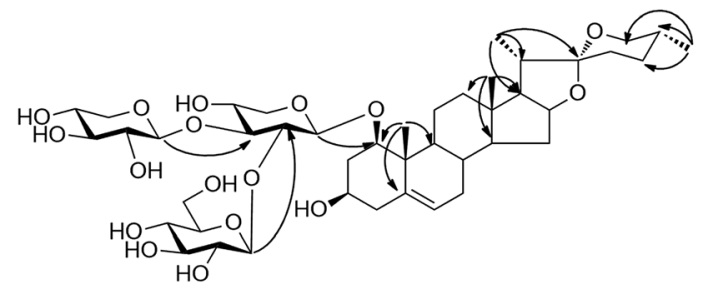

8

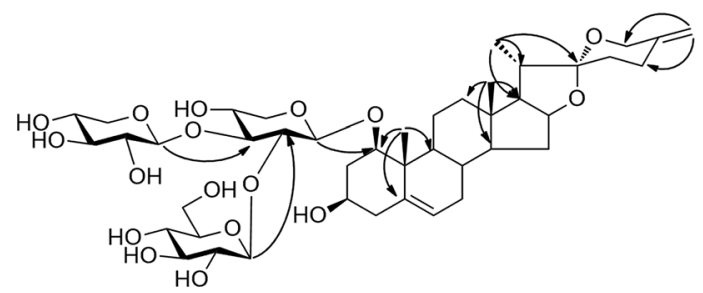

9

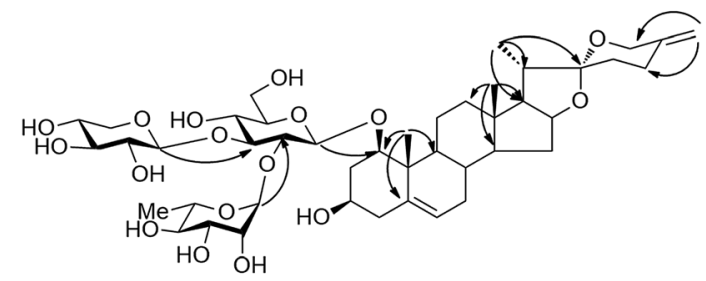

10

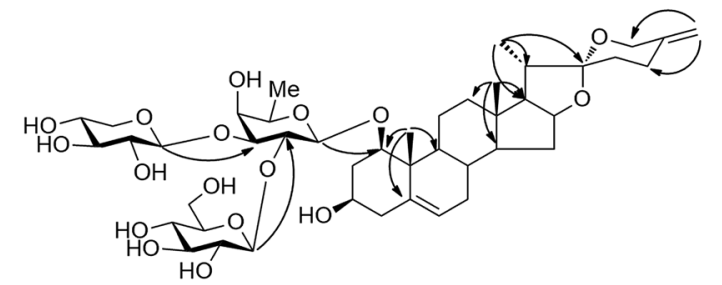

Fig. 1 Key HMBC correlations ofcompounds 1-10.

was that the $\beta$-glucopyranoside unit was replaced by a $\beta$-xylopyranosyl unit in 3. The HMBC correlations (Fig. 1) between the anomeric proton signal at $\delta_{\mathrm{H}} 5.43\left(\mathrm{~d}, J=7.7\right.$, Glu $\left.\mathrm{H}-1^{\prime \prime}\right)$ to $\delta_{\mathrm{C}} 79.2$ (Xyl C-2'), from $\delta_{\mathrm{H}} 5.27\left(\mathrm{~d}, J=7.7 \mathrm{~Hz}, \mathrm{Xyl} \mathrm{H}-1^{\prime \prime \prime}\right.$ ) to $\delta_{\mathrm{C}} 81.6$ (Xyl C$\left.3^{\prime}\right)$ and from $\delta_{\mathrm{H}} 4.95\left(\mathrm{~d}, J=7.0 \mathrm{~Hz}\right.$, Xyl H-1') to $\delta_{\mathrm{C}} 82.6$ (Agly C-1) proved that the sequence of the sugar chain was Glu- $(1 \rightarrow 2)$-[Xyl$(1 \rightarrow 3)]$-Xyl and that the glycosidic site was at C-1. Thus, compound 3 was $(25 S)$-ruscogenin-1-O- $\beta$-D-glucopyranosyl-( $(1 \rightarrow 2)$ $[\beta$-D-xylopyranosyl-( $1 \rightarrow 3)]-\beta$-D-xylopyrano side.

The HRESI-QTOF-MS spectrum of compound $4(\mathrm{~m} / \mathrm{z} 879.4344$ $[\mathrm{M}+\mathrm{Na}]^{+}$calcd 879.4349) supported a molecular formula of $\mathrm{C}_{43} \mathrm{H}_{68} \mathrm{O}_{17}$, the same as compound 3. The NMR data of 4 (Tables 1-4) obtained from 1D and 2D NMR spectra were similar to those of 3. The chemical shifts at $\delta_{\mathrm{C}} 31.50$ (C-23), 28.94 (C-24), 30.27 (C$25)$ and $66.53(\mathrm{C}-26)$ in the ${ }^{13} \mathrm{C}-\mathrm{NMR}$ spectrum had lower field resonances than those of 3 . Together with the characteristic absorptions of a $25(R)$ spiroketal unit at $982,921,902,870 \mathrm{~cm}^{-1}$, and $902>921 \mathrm{~cm}^{-1}$ in the IR spectrum, these results indicated that the configuration at C-25 was $R$. The aglycone moiety of compound 4 was identified as (25R)-ruscogenin by comparison of the NMR data of $\mathbf{4}$ to those of compound $\mathbf{1}$. The sequence of the sugar chain and the glycosidic position of $\mathbf{4}$, determined $d$ by HMBC and TOCSY experiments, showed that $\mathbf{4}$ contained the same sugar chain at $\mathrm{C}-1$ as compound 3 . The structure of compound 4 was therefore (25R)-ruscogenin-1-O- $\beta$-D-glucopyranosyl-( $1 \rightarrow 2)$-[ $[\beta-\mathrm{D}-\mathrm{xyl}$ lopyranosyl-( $1 \rightarrow 3)]-\beta$-D-xy lopyranoside. Key HMBC, HSQC and TOCSY correlations are shown in Fig. 1 and the ESI data. $\dagger$

The molecular formula of compound $\mathbf{5}$ was established unequivocally as $\mathrm{C}_{44} \mathrm{H}_{70} \mathrm{O}_{17}$ from the HRESI-QTOF-MS spectrum $\left(\mathrm{m} / \mathrm{z} 871.4702[\mathrm{M}+\mathrm{H}]^{+}\right.$, calcd 871.4686). The IR spectrum indicated the presence of a hydroxyl and a $25(R)$ spiroketal unit. The 
Table $2{ }^{13} \mathrm{C}$ NMR data for sugar moieties of compounds $1-10^{a}\left(\delta\right.$ in ppm, pyridine- $\left.d_{5}\right)$

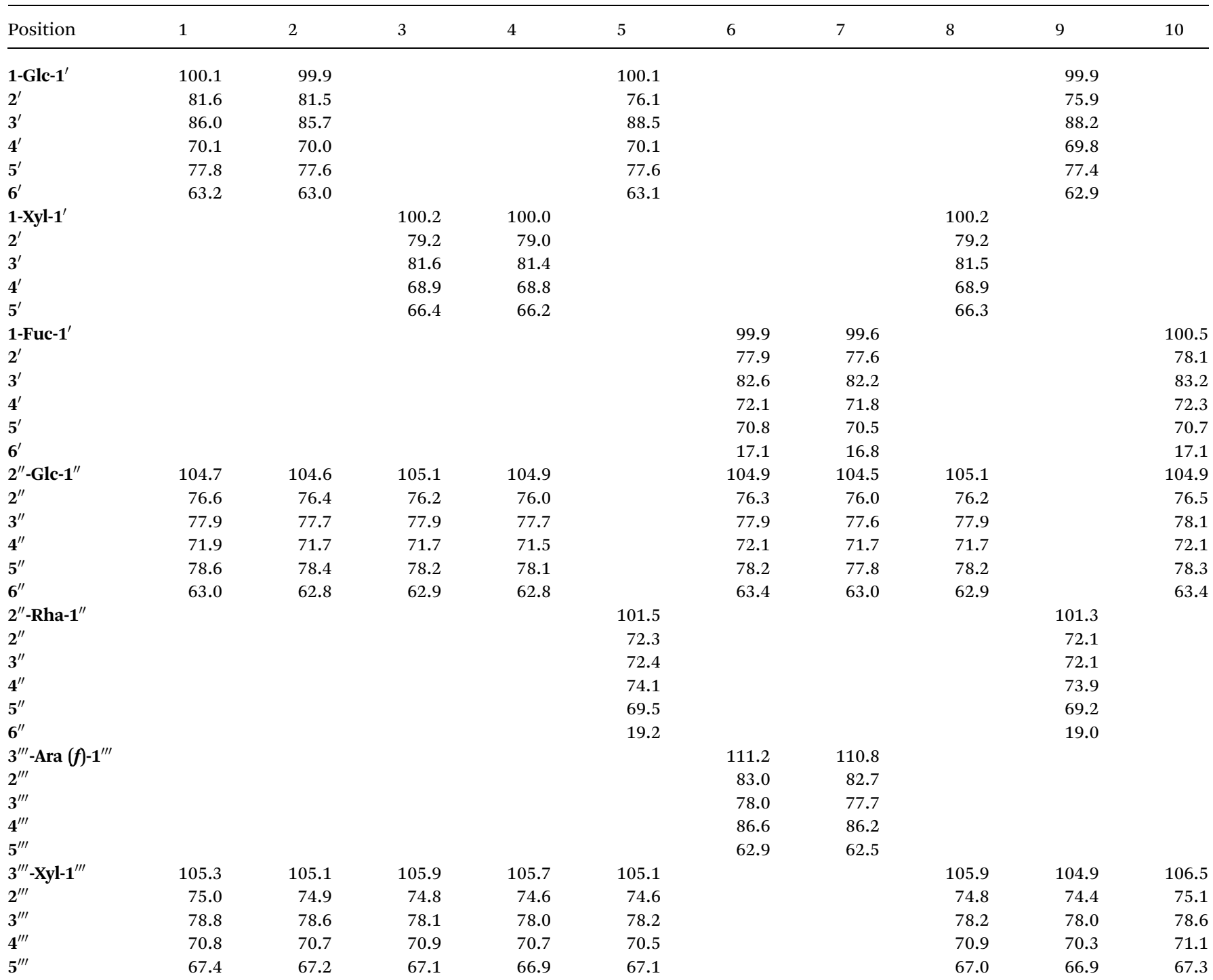

${ }^{a}$ NMR data were measured at $500 \mathrm{MHz}$ for ${ }^{1} \mathrm{H}$ and at $125 \mathrm{MHz}$ for ${ }^{13} \mathrm{C}$ in pyridine- $d_{5}$. Assignments are based on TCOSY, HSQC, and HMBC experiments.

aglycone moiety of $\mathbf{5}$ was established as $25(R)$-ruscogenin by comparison of the NMR data of 5 (Tables 1-4) to those of 2 , and the glycosidic site was identified as C-1. A detailed analysis of 1D and 2D NMR data of 5 compared to those reported for parisverticoside $A,{ }^{38}$ and parisyunnanoside $\mathrm{G},{ }^{39}$ showed that they shared the same sugar moiety. The sequence of the sugar chain was established as Rha-( $1 \rightarrow 2)$-[Xyl-( $1 \rightarrow 3)]$-Glu by HMBC, HSQC and TOCSY correlations. Thus, compound 5 was $(25 R)$-ruscogenin-1-O- $\alpha$-L-rhamnopyranosy $\mathrm{l}-(1 \rightarrow 2)-[\beta$-D-xylopyranosyl-( $(1 \rightarrow 3)]-$ $\beta$-D-glucopyranoside.

Compound 6 has a molecular formula of $\mathrm{C}_{44} \mathrm{H}_{70} \mathrm{O}_{17}$, as indicated by the HRESI-QTOF-MS spectrum $(\mathrm{m} / z \text { 893.4461 [M + Na] }]^{+}$, calcd 893.4505). The aglycone moiety of 6 was established as (25S)-ruscogenin by comparison of the NMR data of 6 (Tables 14) to those of 3. The ${ }^{1} \mathrm{H}$-NMR spectrum showed three anomeric proton signals $\left[\delta_{\mathrm{H}} 5.36(1 \mathrm{H}, \mathrm{d}, J=7.7 \mathrm{~Hz}), 6.10(1 \mathrm{H}, \mathrm{d}, J=2.4 \mathrm{~Hz})\right.$ and $4.79(1 \mathrm{H}, \mathrm{d}, J=7.5 \mathrm{~Hz})]$, giving HSQC correlations with three anomeric carbon signals at $\delta_{\mathrm{C}} 104.5,110.8$ and 99.6, respectively. The HMBC correlations (Fig. 1) of the anomeric proton signal in 6 at $\delta_{\mathrm{H}} 5.36\left(\mathrm{~d}, J=7.7\right.$, Glu H-1") to $\delta_{\mathrm{C}} 77.6($ Fuc C-2' $)$, from $\delta_{\mathrm{H}} 6.10$ $\left(\mathrm{d}, J=2.4 \mathrm{~Hz}\right.$, Ara $\left.(f) \mathrm{H}-1^{\prime \prime \prime}\right)$ to $\delta_{\mathrm{C}} 82.2\left(\right.$ Fuc C-3') and from $\delta_{\mathrm{H}} 4.79$ (d, $J=7.5 \mathrm{~Hz}$, Fuc $\mathrm{H}-1^{\prime}$ ) to $\delta_{\mathrm{C}} 82.5$ (Agly C-1) proved that the sequence of the sugar chain was Glu-( $1 \rightarrow 2)$-[Ara $(f)-(1 \rightarrow 3)]$-Fuc and that the glycosidic site was at C-1. HSQC and TOCSY correlations are shown in the ESI data. $\uparrow$ The structure of $\mathbf{6}$ was therefore established as (25S)-ruscogenin-1-O- $\beta$-D-glucopyranosyl$(1 \rightarrow 2)$-[ $\alpha$-L-arabinofuranosyl- $(1 \rightarrow 3)]-\beta$-D-fucopyranoside.

Compound 7 has the same molecular formula as compound 6 $\left(\mathrm{C}_{44} \mathrm{H}_{70} \mathrm{O}_{17}\right)$ from the HRESI-QTOF-MS spectrum $(\mathrm{m} / z$ 893.4461 $[\mathrm{M}+\mathrm{Na}]^{+}$, calcd 893.4505), and similar NMR data (Tables 1-4). The only difference in the chemical shifts at $\delta_{\mathrm{C}} \mathrm{C}-23, \mathrm{C}-24, \mathrm{C}-25$ and $\mathrm{C}-26$ of 7 was the lower field resonances compared to those of 6 in the ${ }^{13} \mathrm{C}-\mathrm{NMR}$ spectrum, indicating that 6 and 7 were a pair of C-25 epimers. The aglycone moiety of compound 7 was 


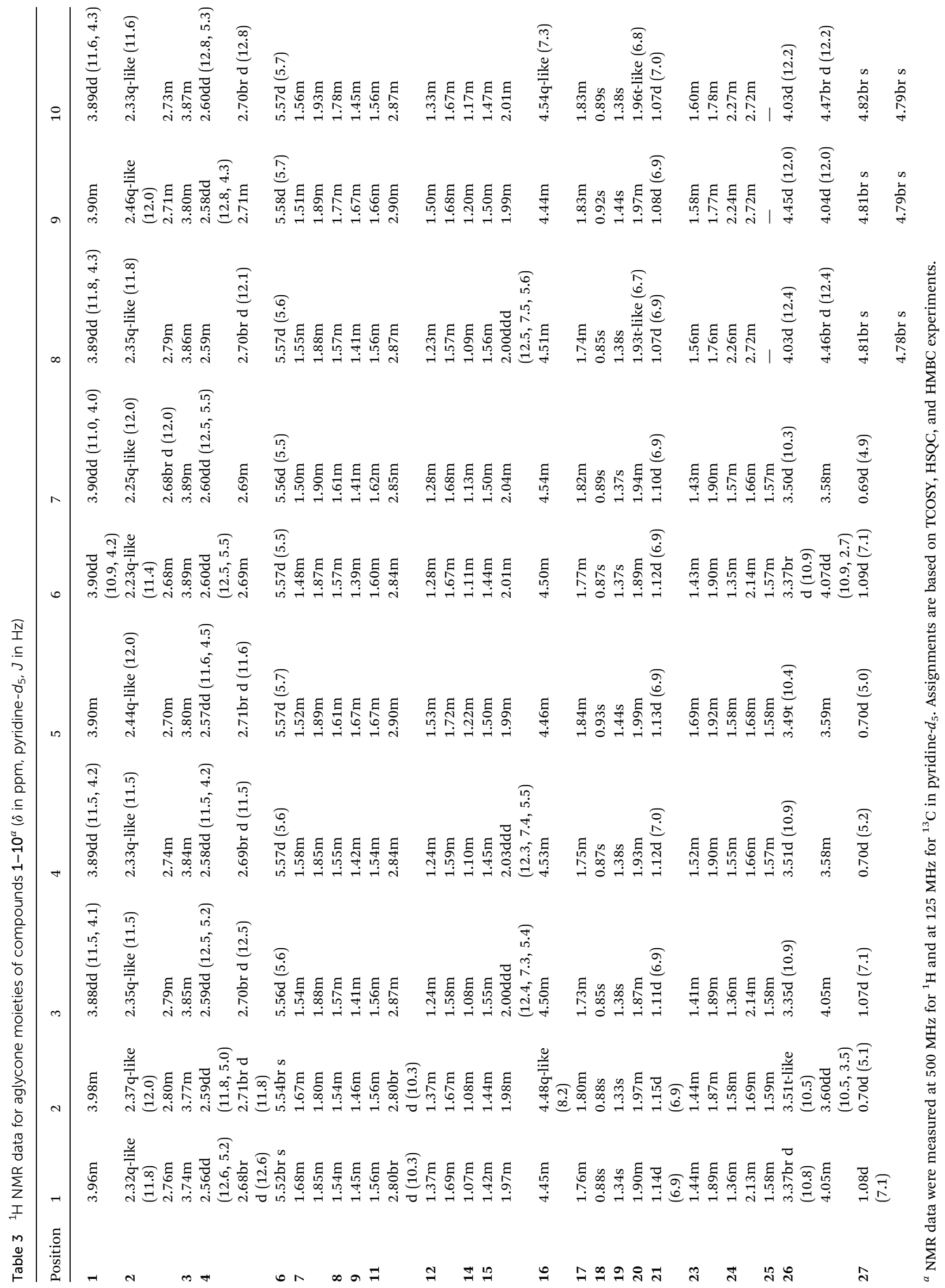


Table $4{ }^{1} \mathrm{H}$ NMR data for sugar moieties of compounds $1-10^{a}$ ( $\delta$ in ppm, pyridine- $d_{5}, \mathrm{~J}$ in $\mathrm{Hz}$ )

\begin{tabular}{|c|c|c|c|c|c|c|c|c|c|c|}
\hline Position & 1 & 2 & 3 & 4 & 5 & 6 & 7 & 8 & 9 & 10 \\
\hline 1-Glc-1' & $\begin{array}{l}5.04 d \\
(8.0)\end{array}$ & $\begin{array}{l}5.05 d \\
(7.7)\end{array}$ & & & $\begin{array}{l}4.84 d \\
(7.7)\end{array}$ & & & & $\begin{array}{l}4.83 d \\
(7.8)\end{array}$ & \\
\hline $2^{\prime}$ & $\begin{array}{l}4.45 \mathrm{dd} \\
(4.2,8.0)\end{array}$ & $4.45 \mathrm{~m}$ & & & $\begin{array}{l}4.21 \mathrm{~d} \\
(7.7)\end{array}$ & & & & $\begin{array}{l}4.21 \mathrm{~d} \\
(7.8)\end{array}$ & \\
\hline $3^{\prime}$ & $4.23 \mathrm{~m}$ & $4.23 \mathrm{~m}$ & & & $\begin{array}{l}4.09 d \\
(8.7)\end{array}$ & & & & $\begin{array}{l}4.08 d \\
(9.0)\end{array}$ & \\
\hline $4^{\prime}$ & $3.97 \mathrm{~m}$ & $3.96 \mathrm{~m}$ & & & $3.88 \mathrm{~m}$ & & & & $3.88 \mathrm{~m}$ & \\
\hline $5^{\prime}$ & $3.83 \mathrm{~m}$ & $3.85 \mathrm{~m}$ & & & $3.81 \mathrm{~m}$ & & & & $3.81 \mathrm{~m}$ & \\
\hline \multirow[t]{2}{*}{$6^{\prime}$} & $\begin{array}{l}4.74 d d \\
(11.7,2.7)\end{array}$ & $\begin{array}{l}4.77 d d \\
(11.7,2.7)\end{array}$ & & & $4.51 \mathrm{~m}$ & & & & $4.51 \mathrm{~m}$ & \\
\hline & $\begin{array}{l}4.52 \mathrm{dd} \\
(11.7,3.5)\end{array}$ & $\begin{array}{l}4.54 d d \\
(11.7,4.4)\end{array}$ & & & $4.24 \mathrm{~m}$ & & & & $4.22 \mathrm{~m}$ & \\
\hline 1-Xyl-1' & & & $\begin{array}{l}4.95 d \\
(7.0)\end{array}$ & $\begin{array}{l}4.95 \mathrm{~d} \\
(7.0)\end{array}$ & & & & $\begin{array}{l}4.95 d \\
(7.0)\end{array}$ & & \\
\hline $2^{\prime}$ & & & $\begin{array}{l}\text { 4.80dd } \\
(7.0,9.0)\end{array}$ & $\begin{array}{l}\text { 4.79dd } \\
(7.0,9.0)\end{array}$ & & & & $4.81 \mathrm{~m}$ & & \\
\hline 3 & & & $4.30 \mathrm{~m}$ & $4.29 \mathrm{~m}$ & & & & $4.29 \mathrm{~m}$ & & \\
\hline 4 & & & $4.48 \mathrm{~m}$ & $4.46 \mathrm{~m}$ & & & & $4.48 \mathrm{~m}$ & & \\
\hline $5^{\prime}$ & & & $\begin{array}{l}3.71 \mathrm{~m} \\
4.28 \mathrm{~m}\end{array}$ & $\begin{array}{l}3.72 \mathrm{~m} \\
4.26 \mathrm{~m}\end{array}$ & & & & $\begin{array}{l}3.72 \mathrm{~m} \\
4.28 \mathrm{~m}\end{array}$ & & \\
\hline 1-Fuc-1 ${ }^{\prime}$ & & & & & & $\begin{array}{l}4.78 d \\
(7.9)\end{array}$ & $\begin{array}{l}4.79 d \\
(7.5)\end{array}$ & & & $\begin{array}{l}4.85 d \\
(7.6)\end{array}$ \\
\hline $2^{\prime}$ & & & & & & $\begin{array}{l}4.61 d d \\
(9.6,7.5)\end{array}$ & $\begin{array}{l}4.64 d d \\
(9.6,7.6)\end{array}$ & & & $4.24 \mathrm{~m}$ \\
\hline $3^{\prime}$ & & & & & & $\begin{array}{l}4.13 d d \\
(9.6,3.4)\end{array}$ & $\begin{array}{l}4.14 d d \\
(9.6,3.4)\end{array}$ & & & $4.20 \mathrm{~m}$ \\
\hline $\mathbf{4}^{\prime}$ & & & & & & $4.23 \mathrm{~m}$ & $4.24 \mathrm{~m}$ & & & $4.24 \mathrm{~m}$ \\
\hline $5^{\prime}$ & & & & & & $3.59 \mathrm{~m}$ & $3.61 \mathrm{~m}$ & & & $3.74 \mathrm{~m}$ \\
\hline $6^{\prime}$ & & & & & & $\begin{array}{l}1.48 d \\
(6.3)\end{array}$ & $\begin{array}{l}1.48 d \\
(6.3)\end{array}$ & & & $\begin{array}{l}1.54 d \\
(6.2)\end{array}$ \\
\hline $2^{\prime \prime}-$ Glc-1 ${ }^{\prime \prime}$ & $\begin{array}{l}5.52 \mathrm{~d} \\
(7.7)\end{array}$ & $\begin{array}{l}5.52 \mathrm{~d} \\
(7.7)\end{array}$ & $\begin{array}{l}5.43 \mathrm{~d} \\
(7.8)\end{array}$ & $\begin{array}{l}5.42 \mathrm{~d} \\
(7.8)\end{array}$ & & $\begin{array}{l}5.33 d \\
(7.8)\end{array}$ & $\begin{array}{l}5.36 \mathrm{~d} \\
(7.7)\end{array}$ & $\begin{array}{l}5.44 d \\
(7.8)\end{array}$ & & $\begin{array}{l}5.45 d \\
(7.9)\end{array}$ \\
\hline $2^{\prime \prime}$ & $4.17 \mathrm{~m}$ & $4.18 \mathrm{~m}$ & $4.15 \mathrm{~m}$ & $4.13 \mathrm{~m}$ & & $4.09 \mathrm{~m}$ & $4.06 \mathrm{~m}$ & $4.14 \mathrm{~m}$ & & $4.11 \mathrm{~m}$ \\
\hline $3^{\prime \prime}$ & $4.33 \mathrm{~m}$ & $4.36 \mathrm{~m}$ & $4.28 \mathrm{~m}$ & $\begin{array}{l}4.27 \mathrm{dd} \\
(7.5,3.1)\end{array}$ & & $4.26 \mathrm{~m}$ & $4.23 \mathrm{~m}$ & $4.28 \mathrm{~m}$ & & $4.24 \mathrm{~m}$ \\
\hline $\mathbf{4}^{\prime \prime}$ & $4.31 \mathrm{~m}$ & $4.35 \mathrm{~m}$ & $4.27 \mathrm{~m}$ & $4.26 \mathrm{~m}$ & & $4.23 \mathrm{~m}$ & $4.23 \mathrm{~m}$ & $4.27 \mathrm{~m}$ & & $4.19 \mathrm{~m}$ \\
\hline $5^{\prime \prime}$ & $4.10 \mathrm{~m}$ & $4.10 \mathrm{~m}$ & $3.95 \mathrm{~m}$ & $3.95 \mathrm{~m}$ & & $3.86 \mathrm{~m}$ & $3.84 \mathrm{~m}$ & $3.95 \mathrm{~m}$ & & $3.93 \mathrm{~m}$ \\
\hline $6^{\prime \prime}$ & $4.50 \mathrm{~m}$ & $4.23 \mathrm{~m}$ & $4.46 \mathrm{~m}$ & $4.45 \mathrm{~m}$ & & $\begin{array}{l}\text { 4.38dd } \\
(11.4,4.6)\end{array}$ & $\begin{array}{l}4.40 \mathrm{br} \\
\mathrm{d}(11.3)\end{array}$ & $4.46 \mathrm{~m}$ & & $\begin{array}{l}4.42 d d \\
(11.5,4.6)\end{array}$ \\
\hline & $4.23 \mathrm{~m}$ & $4.50 \mathrm{~m}$ & $\begin{array}{l}\text { 4.61dd } \\
(11.6,2.8)\end{array}$ & $\begin{array}{l}4.61 \mathrm{br} \\
\mathrm{d}(11.7)\end{array}$ & & $4.50 \mathrm{~m}$ & $4.51 \mathrm{~m}$ & $\begin{array}{l}4.63 \mathrm{br} \\
\mathrm{d}(11.6)\end{array}$ & & $\begin{array}{l}4.60 d d \\
(11.5,2.9)\end{array}$ \\
\hline $2^{\prime \prime}$-Rha-1 ${ }^{\prime \prime}$ & & & & & $6.47 \mathrm{br} \mathrm{s}$ & & & & $6.47 \mathrm{br} \mathrm{s}$ & \\
\hline $2^{\prime \prime}$ & & & & & $4.82 \mathrm{~m}$ & & & & $4.82 \mathrm{~m}$ & \\
\hline $3^{\prime \prime}$ & & & & & $\begin{array}{l}\text { 4.61dd } \\
(8.7,4.6)\end{array}$ & & & & $\begin{array}{l}4.62 \mathrm{br} \\
\mathrm{d}(9.5)\end{array}$ & \\
\hline $4^{\prime \prime}$ & & & & & $\begin{array}{l}4.35 \text { td } \\
(9.5,3.8)\end{array}$ & & & & $4.34 \mathrm{~m}$ & \\
\hline $5^{\prime \prime}$ & & & & & $\begin{array}{l}4.88 d d \\
(9.5,6.2)\end{array}$ & & & & $4.86 \mathrm{~m}$ & \\
\hline $6^{\prime \prime}$ & & & & & $\begin{array}{l}1.80 \mathrm{~d} \\
(6.2)\end{array}$ & & & & $\begin{array}{l}1.80 \mathrm{~d} \\
(6.2)\end{array}$ & \\
\hline $3^{\prime \prime \prime}-\operatorname{Ara}(f)-1^{\prime \prime \prime}$ & & & & & & $\begin{array}{l}6.10 d \\
(2.3)\end{array}$ & $\begin{array}{l}6.10 \mathrm{~d} \\
(2.4)\end{array}$ & & & \\
\hline $2^{\prime \prime \prime}$ & & & & & & $4.95 \mathrm{~m}$ & $4.97 \mathrm{~m}$ & & & \\
\hline $3^{\prime \prime \prime}$ & & & & & & $4.83 \mathrm{~m}$ & $4.83 \mathrm{~m}$ & & & \\
\hline $4^{\prime \prime \prime}$ & & & & & & $4.73 \mathrm{~m}$ & $4.77 \mathrm{~m}$ & & & \\
\hline $5^{\prime \prime \prime}$ & & & & & & $\begin{array}{l}4.18 \mathrm{~m} \\
4.28 \mathrm{dd} \\
(11.8,3.5)\end{array}$ & $\begin{array}{l}4.21 \mathrm{~m} \\
4.32 \mathrm{br} \\
\mathrm{d}(11.8)\end{array}$ & & & \\
\hline $3^{\prime \prime \prime}-\mathbf{x y l}-1^{\prime \prime \prime}$ & $\begin{array}{l}5.29 d \\
(7.7)\end{array}$ & $\begin{array}{l}5.28 \mathrm{~d} \\
(7.7)\end{array}$ & $\begin{array}{l}5.27 d \\
(8.0)\end{array}$ & $\begin{array}{l}5.26 \mathrm{~d} \\
(8.0)\end{array}$ & $\begin{array}{l}4.96 \mathrm{~d} \\
(8.0)\end{array}$ & & & $\begin{array}{l}5.28 d \\
(8.4)\end{array}$ & $\begin{array}{l}4.96 \mathrm{~d} \\
(7.6)\end{array}$ & $\begin{array}{l}5.26 \mathrm{~d} \\
(8.2)\end{array}$ \\
\hline $2^{\prime \prime \prime}$ & $4.02 \mathrm{~m}$ & $4.05 \mathrm{~m}$ & $4.00 \mathrm{br} \mathrm{d}(8.0)$ & $\begin{array}{l}\text { 4.00dd } \\
(8.0,3.1)\end{array}$ & $\begin{array}{l}\text { 4.00dd } \\
(8.0,3.5)\end{array}$ & & & $\begin{array}{l}3.98 d d \\
(8.4,3.2)\end{array}$ & $4.00 \mathrm{~m}$ & $\begin{array}{l}3.97 \mathrm{br} \\
\mathrm{d}(8.2)\end{array}$ \\
\hline
\end{tabular}


Table 4 (Contd.)

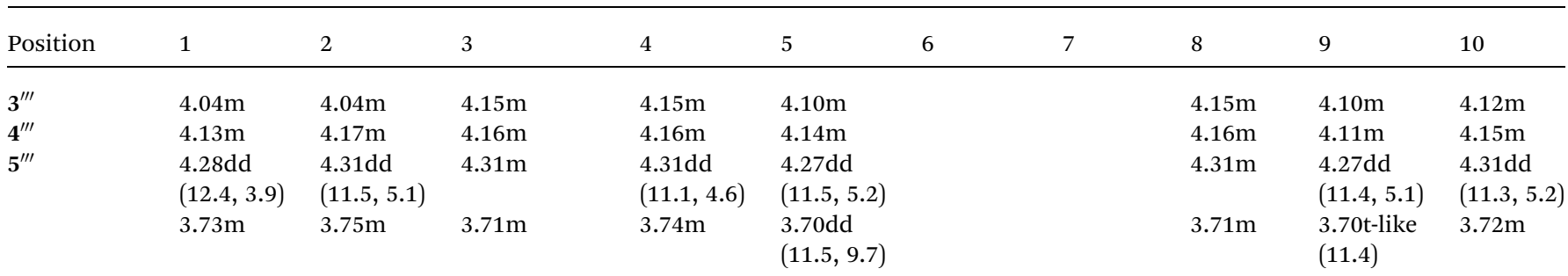

${ }^{a} \mathrm{NMR}$ data were measured at $500 \mathrm{MHz}$ for ${ }^{1} \mathrm{H}$ and at $125 \mathrm{MHz}$ for ${ }^{13} \mathrm{C}$ in pyridine- $d_{5}$. Assignments are based on TCOSY, HSQC, and HMBC experiments.

identified as $(25 R)$-ruscogenin by comparison of the NMR data to those of 2. HMBC, HSQC and TOCSY experiments indicated that 7 had the same sequence of the sugar chain and glycosidic position as compound 6. Key HMBC and HSQC correlations are shown in Fig. 1 and the ESI data. $\dagger$ The structure of 7 was therefore established as (25R)-ruscogenin-1-O- $\beta$-D-glucopyranosyl-( $(1 \rightarrow 2)$-[ $\alpha$-L-arabinofuranosyl- $(1 \rightarrow 3)]$ - $\beta$-D-fucopyranoside.

Compound 8 has the molecular formula $\mathrm{C}_{43} \mathrm{H}_{66} \mathrm{O}_{17}$, as deduced from the HRESI-QTOF-MS data $(\mathrm{m} / \mathrm{z} 877.4188$ [M + $\mathrm{Na}]^{+}$, calcd 877.4192). The ${ }^{1} \mathrm{H}$ - and ${ }^{13} \mathrm{C}-\mathrm{NMR}$ data (Tables $1-4$ ) of 8 were similar to those of $\mathbf{3}$, with the exception of some differences in the carbon signals due to the presence of an exoolefinic group $\left(\delta_{\mathrm{H}} 4.81,4.78 ; \delta_{\mathrm{C}} 144.3,108.6\right)$ and the disappearance of signals for a secondary methyl $\left(\mathrm{CH}_{3}-27\right)$ in $\mathbf{8}$. The location of an exo-double bond $\left(\Delta^{25(27)}\right)$ was confirmed by the long-range correlations of $\mathrm{H}-27\left(\delta_{\mathrm{H}} 4.81,4.78\right)$ to C-24 $\left(\delta_{\mathrm{C}} 28.8\right)$, C-25 $\left(\delta_{\mathrm{C}} 144.3\right)$ and C-26 $\left(\delta_{\mathrm{C}} 64.9\right)$ in the HMBC spectrum indicating that the aglycone moiety was neoruscogenin. ${ }^{37}$ The sugar moiety and glycosidic site of $\mathbf{8}$ were established to be the same as those of 3 by HMBC and TOCSY experiments. Key long-range correlations are shown in Fig. 1 and the ESI data. $\dagger$ Thus, 8 was characterized as neoruscogenin-1-O- $\beta$-D-glucopyranosyl- $(1 \rightarrow 2)$ [ $\beta$-D-xylopyr-anosyl- $(1 \rightarrow 3)]-\beta$-D-xylopyranoside.

The molecular formula of compound $\mathbf{9}$ was determined to be $\mathrm{C}_{43} \mathrm{H}_{68} \mathrm{O}_{17}$ from the pseudo-molecular ion peak $[\mathrm{M}+\mathrm{H}]^{+}$at $\mathrm{m} / \mathrm{z}$ 869.4529 (calcd 869.4529) in the HRESI-QTOF-MS, differing from that of 5 by $2 \mathrm{Da}$, and corresponding to an additional double bond. The aglycone moiety of 9 was established as neoruscogenin by comparison of $1 \mathrm{D}$ and $2 \mathrm{D}$ NMR spectra (Tables 1-4) of compound 9 to those of 8 . A detailed analysis of NMR data of 9 in comparison with those of $\mathbf{5}$ showed that $\mathbf{9}$ had the same sugar moiety and glycosidic site as $\mathbf{5}$. The sequence of the sugar chain and the glycosidic position of $\mathbf{9}$ were further confirmed by HMBC, HSQC and TOCSY experiments. Thus, compound 9 was

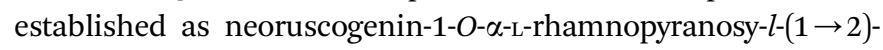
$[\beta$-D-xylop yranosyl- $(1 \rightarrow 3)]-\beta$-D-glucopyranoside.

The molecular formula of compound $\mathbf{1 0}$ was determined by HRESI-QTOF-MS to be $\mathrm{C}_{44} \mathrm{H}_{68} \mathrm{O}_{17}(\mathrm{~m} / z \text { 891.4321 [M }+\mathrm{Na}]^{+}$, calcd 891.4349). The NMR data of 10 (Tables 1-4) based on HSQC, HMBC and TOCSY were similar to those of $\mathbf{1 1}\{(25 R)$ ruscogenin-1-O- $\beta$-D-glucopyranosyl-( $1 \rightarrow 2)$-[ $\beta$-D-xylopyranosyl$(1 \rightarrow 3)]-\beta$-D-fucopyranoside, Fig. 2$\},{ }^{30}$ except for the appearance

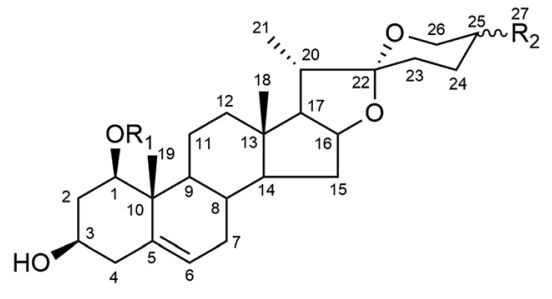

\begin{tabular}{lll} 
& $\mathrm{R} 1$ & \multicolumn{1}{c}{$\mathrm{R} 2$} \\
1 & $\mathrm{~S}_{1}$ & $\mathrm{CH}_{3}(25 \mathrm{~S})$ \\
2 & $\mathrm{~S}_{1}$ & $\mathrm{CH}_{3}(25 \mathrm{R})$ \\
3 & $\mathrm{~S}_{2}$ & $\mathrm{CH}_{3}(25 \mathrm{~S})$ \\
4 & $\mathrm{~S}_{2}$ & $\mathrm{CH}_{3}(25 \mathrm{R})$ \\
5 & $\mathrm{~S}_{3}$ & $\mathrm{CH}_{3}(25 \mathrm{R})$ \\
6 & $\mathrm{~S}_{4}$ & $\mathrm{CH}_{3}(25 \mathrm{~S})$ \\
7 & $\mathrm{~S}_{4}$ & $\mathrm{CH}_{3}(25 \mathrm{R})$ \\
8 & $\mathrm{~S}_{2}$ & $=\mathrm{CH}_{2}$ \\
9 & $\mathrm{~S}_{3}$ & $=\mathrm{CH}_{2}$ \\
10 & $\mathrm{~S}_{5}$ & $=\mathrm{CH}_{2}$ \\
11 & $\mathrm{~S}_{5}$ & $\mathrm{CH}_{3}(25 \mathrm{R})$ \\
12 & $\mathrm{~S}_{5}$ & $\mathrm{CH}_{3}(25 \mathrm{~S})$ \\
13 & $\mathrm{~S}_{3}$ & $\mathrm{CH}_{3}(25 \mathrm{~S})$
\end{tabular}

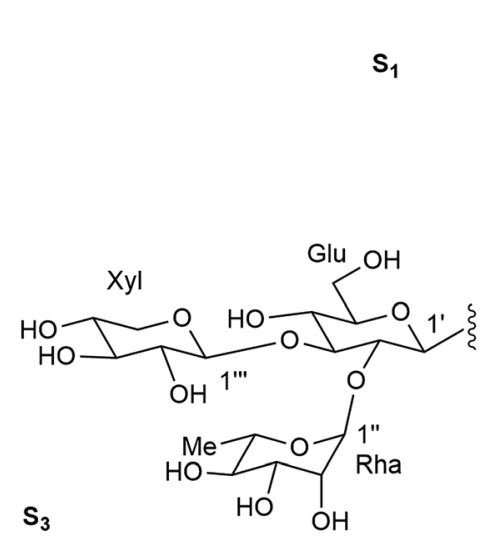

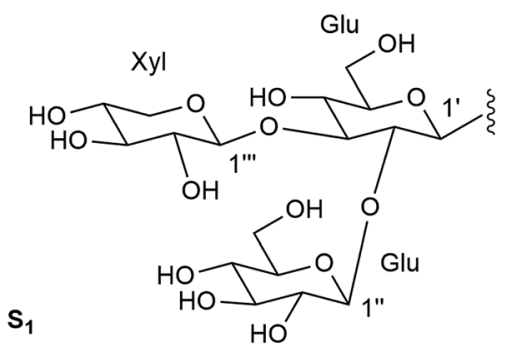

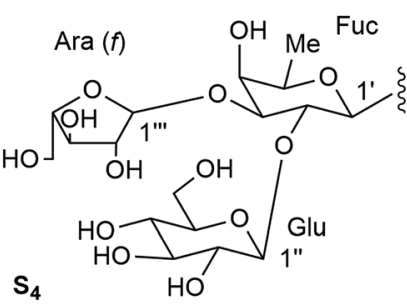

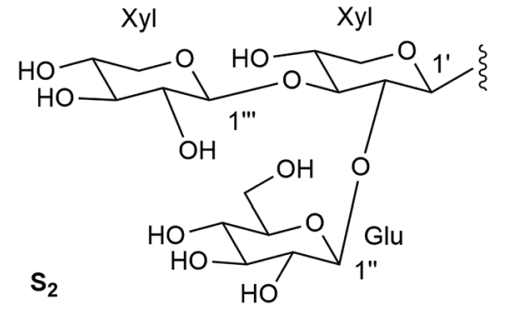

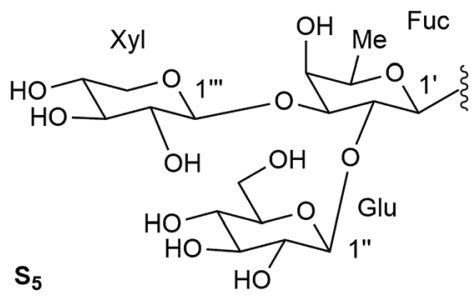

Fig. 2 Chemical structures of compounds 1-13. 
of signals for an exo-olefinic group $\left(\delta_{\mathrm{H}} 4.82,4.79 ; \delta_{\mathrm{C}} 144.6\right.$, 108.6) and the disappearance of the signals for a secondary methyl $\left(\mathrm{CH}_{3}-27\right)$ in 10. The location of an exo-double bond $\left(\Delta^{25(27)}\right)$ was confirmed by the long-range correlations of $\mathrm{H}-27$ $\left(\delta_{\mathrm{H}} 4.82,4.78\right)$ to $\mathrm{C}-24\left(\delta_{\mathrm{C}} 29.0\right), \mathrm{C}-25\left(\delta_{\mathrm{C}} 144.6\right)$ and C-26 $\left(\delta_{\mathrm{C}}\right.$ $65.0)$ in the HMBC spectrum. The sequence of the sugar chain and the glycosidic position of $\mathbf{1 0}$ determined by HMBC and TOCSY experiments suggested that $\mathbf{1 0}$ had the same sugar moiety and glycosidic site as $\mathbf{1 1}$. Therefore, $\mathbf{1 0}$ was characterized as neoruscogenin-1- $O$ - $\beta$-D-glucopyranosyl-( $1 \rightarrow 2)$-[ $\beta$-D-xylopyranosyl- $(1 \rightarrow 3)]$ - $\beta$-D-fucopyranoside.

The three known compounds were identified as $(25 R)$-ruscogenin-1-O- $\beta$-D-glucopyranosyl-( $1 \rightarrow 2)$-[ $\beta$-D-xylopyranosyl- $(1 \rightarrow 3)]$ $\beta$-D-fucopyranoside (11), ${ }^{30}(25 S)$-ruscogenin-1-O- $\beta$-D-glucopyran osyl- $(1 \rightarrow 2)$-[ $\beta$-D-xylopyranosyl- $(1 \rightarrow 3)]-\beta$-D-fucopyranoside $(12),{ }^{30}$ and $(25 S)$-ruscogenin-1-O- $\alpha$-L-rhamnopyranosyl-( $(1 \rightarrow 2)$-[ $\beta$-D-xylopyranosyl-( $(1 \rightarrow 3)]-\beta$-D-glucopyranoside $(13)^{40}$ by comparison of spectroscopic data with data reported in the literature.

According to the features of the chemical structures shown in Fig. 2, compounds 1-13 can be divided into three groups based on their aglycone moiety, including the $(25 S)$-ruscogenin group (compounds 1, 3, 6, 12 and 13), (25R)-ruscogenin group (compounds 2, 4, 5, 7 and 11), and neoruscogenin group (compounds 8, $\mathbf{9}$ and 10). Compounds $\mathbf{3}, \mathbf{4}$ and $\mathbf{8}$ share the same A-E rings and Glu-( $1 \rightarrow 2)$-[Xyl-( $1 \rightarrow 3)]$-Xyl glycoside chain at C-1. The only difference between them is that the C-25 configurations of the aglycone moieties are $25 S, 25 R$ and 25,27 doublebond for 3, 4 and 8, respectively. A similar situation prevails for compounds 13, 5 and 9 and for compounds 12, 11 and 10. Compounds $\mathbf{1}$ and 2, and compounds 6 and 7 are two pairs of C$25 S / R$ epimers.

All isolates were tested for their in vitro cytotoxic activity against MDA-MB-435, 95D, HepG2, HeLa, MCF-7 and A549 cell lines. As summarized in Table 5, compounds $\mathbf{1 1}$ and $\mathbf{1 2}$ exhibited the best cytotoxicity against the MDA-MB-435 cell line among all of the cytotoxicity data, with $\mathrm{IC}_{50}$ values of 4.71 and $5.91 \mu \mathrm{M}$, respectively. Compound 5 showed no significant cytotoxicity $\left(\mathrm{IC}_{50}>50 \mu \mathrm{M}\right)$ against HeLa and MCF-7 cell lines. Compounds 7, 8 and $\mathbf{1 1}$ were also inactive against different cell lines: 7 vs. MDA-MB-435, HepG2, MCF-7 and A549 cell lines; 8 vs. HepG2, MCF-7 and A549 cell lines; 11 vs. HepG2 and MCF-7 cell lines. For all tested cell lines, the configurations at C-25 (25R, $25 S$ and 25,27 -double bond) in the aglycone can be deduced to be unrelated to the cytotoxicity of compounds containing $\beta$-D-glu-( $(1 \rightarrow 2)$-[ $[\beta$-D-xyl-( $1 \rightarrow 3)]-\beta$-D-xyl or $\beta$-D-glu- $(1 \rightarrow 2)$ $[\beta$-D-xyl- $(1 \rightarrow 3)]-\beta$-D-glu sugar chains at C-1 because of the almost similar $\mathrm{IC}_{50}$ values of $\mathbf{1 - 4}$ and $\mathbf{8} v \mathrm{vs}$. all cell lines. The C-25R compounds containing a $\beta$-D-glu- $(1 \rightarrow 2)$-[ $\beta$-D-ara- $(1 \rightarrow 3)]-\beta$-D-fuc sugar chain were less active than their epimers $(6$ and $7 v s$. all cell lines). Interestingly, our cytotoxicity data suggest that the C25 configuration does not influence the cytotoxicity of compounds containing $\beta$-D-rha- $(1 \rightarrow 2)-[\beta$-D-xyl- $(1 \rightarrow 3)]-\beta$-D-glu or $\beta$-D-glu- $(1 \rightarrow 2)$-[ $[\beta$-D-xyl- $(1 \rightarrow 3)]-\beta$-D-fuc sugar chains against the 95D cell line $(\mathbf{5}, \mathbf{9}, \mathbf{1 3}, \mathbf{1 0 - 1 2} v s$. 95D). However, these C-25R compounds were less active than their epimers against HeLa, MCF-7 and A549 cell lines (5, 13; 11, 12 vs. HeLa, MCF-7 and A549). Additionally, for HeLa and HepG2 cell lines, C-25S compounds containing a $\beta$-D-glu- $(1 \rightarrow 2)$-[ $[\beta$-D-xyl-( $(1 \rightarrow 3)]-\beta$-D-fuc sugar chain displayed similar cytotoxicity to those of $25,27-$ double bond compounds (10 and $\mathbf{1 2} v s$. HeLa and HepG2). In summary, the configuration at $\mathrm{C}-25$ in the aglycone and the sugar chain may together determine the cytotoxicity of steroidal saponins, and further studies are required to define the underlying chemical and biological mechanisms.

\section{Experimental section}

\section{General}

Optical rotations were measured using a JASCO P-1020 digital polarimeter (JASCO Corporation, Easton, MD, USA). IR data (KBr disks, in $\mathrm{cm}^{-1}$ ) were recorded on a Perkin-Elmer FT-IR Spectra 400 (Perkin-Elmer, Norwalk, CT, USA). NMR spectra using pyridine- $d_{5}$ as the solvent were recorded using a Bruker Avance 500 NMR spectrometer (Bruker Corporation, Faellanden, Switzerland)

Table 5 Cytotoxic effects of compounds 1-13 on human cancer cells $(n=6)$

$\mathrm{IC}_{50}($ means $\pm \mathrm{SD}, \mu \mathrm{M})$

\begin{tabular}{|c|c|c|c|c|c|c|}
\hline Compounds & MDA-MB-435 & $95 \mathrm{D}$ & HepG2 & HeLa & MCF-7 & A549 \\
\hline 1 & $15.99 \pm 1.03$ & $20.13 \pm 1.18$ & $49.68 \pm 1.57$ & $39.98 \pm 1.20$ & $47.30 \pm 1.56$ & $36.35 \pm 1.39$ \\
\hline 2 & $26.01 \pm 0.85$ & $30.00 \pm 0.51$ & $40.52 \pm 0.96$ & $33.42 \pm 1.39$ & $39.12 \pm 1.02$ & $36.01 \pm 1.31$ \\
\hline 3 & $18.07 \pm 1.34$ & $25.67 \pm 0.41$ & $37.17 \pm 1.71$ & $21.58 \pm 1.42$ & $45.82 \pm 1.44$ & $43.53 \pm 1.16$ \\
\hline 4 & $17.68 \pm 2.50$ & $17.83 \pm 0.37$ & $29.48 \pm 1.64$ & $22.23 \pm 1.43$ & $42.16 \pm 1.26$ & $43.20 \pm 1.53$ \\
\hline 5 & $19.63 \pm 0.76$ & $10.82 \pm 0.18$ & $15.26 \pm 1.29$ & $\mathrm{NA}^{a}$ & $\mathrm{NA}^{a}$ & $35.56 \pm 1.46$ \\
\hline 6 & $16.34 \pm 0.60$ & $14.34 \pm 0.33$ & $27.10 \pm 0.84$ & $14.76 \pm 0.52$ & $35.21 \pm 2.02$ & $24.69 \pm 0.76$ \\
\hline 7 & $\mathrm{NA}^{a}$ & $22.15 \pm 1.41$ & $\mathrm{NA}^{a}$ & $42.56 \pm 3.75$ & $\mathrm{NA}^{a}$ & $\mathrm{NA}^{a}$ \\
\hline 8 & $24.52 \pm 0.91$ & $36.12 \pm 1.08$ & $\mathrm{NA}^{a}$ & $24.30 \pm 1.55$ & $\mathrm{NA}^{a}$ & $\mathrm{NA}^{a}$ \\
\hline 9 & $17.54 \pm 1.39$ & $11.09 \pm 0.15$ & $-^{b}$ & $-b$ & $-^{b}$ & $-^{b}$ \\
\hline 10 & $9.74 \pm 0.62$ & $10.64 \pm 0.21$ & $15.48 \pm 0.52$ & $11.02 \pm 0.42$ & $10.02 \pm 0.73$ & $21.25 \pm 1.42$ \\
\hline 11 & $4.71 \pm 0.75$ & $11.62 \pm 2.00$ & $\mathrm{NA}^{a}$ & $26.36 \pm 2.01$ & NA & $23.56 \pm 2.64$ \\
\hline 12 & $5.91 \pm 0.27$ & $11.20 \pm 0.17$ & $12.76 \pm 0.74$ & $8.00 \pm 0.45$ & $17.88 \pm 0.97$ & $8.226 \pm 0.78$ \\
\hline 13 & $9.75 \pm 0.34$ & $19.58 \pm 0.67$ & $15.24 \pm 1.53$ & $14.03 \pm 0.61$ & $16.30 \pm 0.73$ & $13.99 \pm 0.64$ \\
\hline 5-Fluorouracil & $116.8 \pm 13.93$ & $83.55 \pm 10.66$ & $91.9 \pm 16.20$ & $251.3 \pm 19.93$ & $568.3 \pm 54.37$ & $244.8 \pm 21.23$ \\
\hline
\end{tabular}

${ }^{a}$ No activity $\left(\mathrm{IC}_{50}>50 \mu \mathrm{M}\right) .{ }^{b}$ Not measured due to insufficient amount of compounds. 
with tetramethylsilane as the internal standard. ESI-MS, HRESITOF-MS, and HRESI-QTOF-MS experiments were performed on an Agilent 1100 Series MSD Trap mass spectrometer (Agilent Technologies, Santa Clara, CA, USA), Agilent 6210 ESITOF spectrometer, and Agilent 6520 ESIQTOF spectrometer, respectively. Silica gel (100-200 mesh and 200-300 mesh; Qingdao Marine Chemical Factory, Qingdao, China), D101 macroporous resin (Tianjin Pesticide Co., Tianjin, China), and YMC RP-C18 (50 $\mu \mathrm{m}$, YMC, Tokyo, Japan) were used for column chromatography (CC). Preparative high-performance liquid chromatography (HPLC) was carried out using an Agilent 1100 Series HPLC instrument equipped with a diode array detector. Fractions obtained from CC were analyzed by TLC using silica gel GF254 (Qingdao Marine Chemical Factory, Qingdao, China) plates. GC analysis was conducted on an Agilent 6890 gas chromatograph. L-Cysteine methyl ester hydrochloride, trimethylchlorosilane, hexamethyldisilazane, standard D-glucose, D-fucose, L-rhamnose, L-arabinose, and Dxylose were purchased from Sigma-Aldrich Trading Co. Ltd. (Shanghai, China).

\section{Plant material}

Dried roots of $L$. muscari were purchased from Fujian Province, People's Republic of China, in October 2014, and authenticated by one of the authors (B. Y, Y.). A voucher specimen (No. 20141010) was deposited at the herbarium of Jiangsu Key Laboratory of TCM Evaluation and Translational Research, China Pharmaceutical University, Nanjing, China.

\section{Extraction and isolation}

Dried roots of L. muscari (10 kg) were crushed and extracted with $70 \% \operatorname{EtOH}(2 \mathrm{~h}, 3 \times 80 \mathrm{~L})$, and then the extract was concentrated under vacuum to afford a residue. The residue was suspended in $20 \% \mathrm{EtOH}$ and subjected to D101 macroporous resin CC, eluted successively with EtOH- $\mathrm{H}_{2} \mathrm{O}(20: 80,85: 15,95: 5, \mathrm{v} / \mathrm{v})$ to afford a saponin-rich fraction (85\% EtOH eluting fraction, $100 \mathrm{~g})$.

The saponin-rich fraction was subjected to silica gel CC eluted with a gradient of $\mathrm{CHCl}_{3}-\mathrm{MeOH}-\mathrm{H}_{2} \mathrm{O}(90: 10: 1$ to $30: 70: 5, \mathrm{v} / \mathrm{v}$ ) to afford three fractions (Fr. 1-3). Fr. 1 was chromatographed on a silica gel column, eluted with a gradient of $\mathrm{CHCl}_{3}-\mathrm{MeOH}-\mathrm{H}_{2} \mathrm{O}(85: 15: 1.5$ to $70: 30: 3, \mathrm{v} / \mathrm{v})$, to give two sub-fractions (Fr. 1a, 1b). Fr. 2 was chromatographed on an ODS column with a gradient of $\mathrm{MeOH}-\mathrm{H}_{2} \mathrm{O}(40: 60$ to $70: 30, \mathrm{v} / \mathrm{v})$ as the mobile phase to afford two sub-fractions (Fr. 2a, 2b). Fr. 1a was further purified using an Agela Venusil PAH Prep C-18 column, eluted with $\mathrm{CH}_{3} \mathrm{CN}-\mathrm{H}_{2} \mathrm{O}(45: 55, \mathrm{v} / \mathrm{v})$ to yield compounds 1 (15 mg), 2 (20 mg), 3 (20 mg) and 4 (30 mg). Fr. 1b was further purified using an Agela Venusil PAH Prep C-18 column, eluted with $\mathrm{CH}_{3} \mathrm{CN}-\mathrm{H}_{2} \mathrm{O}(50: 50, \mathrm{v} / \mathrm{v})$ to yield compounds 5 (50 mg), 6 (10 mg), 7 (30 mg) and 13 (40 mg). Fr. 2a was further purified using an Agela Venusil PAH Prep C-18 column, eluted with $\mathrm{CH}_{3} \mathrm{CN}-\mathrm{H}_{2} \mathrm{O}(45: 55, \mathrm{v} / \mathrm{v})$ to yield compounds 8 (60 mg), 11 (300 mg) and 12 (200 mg). Compounds 9 (8 mg) and $\mathbf{1 0}(10 \mathrm{mg})$ were isolated from Fr. 2b using an Agela Venusil PAH Prep C-18 column, eluted with $\mathrm{CH}_{3} \mathrm{CN}-\mathrm{H}_{2} \mathrm{O}(50: 50, \mathrm{v} / \mathrm{v})$.

\section{Characterization of new compounds}

Compound 1. White amorphous powder; $[\alpha]_{23}^{\mathrm{D}}-46.89$ (c 0.10, MeOH); IR (KBr) $\nu_{\max }: 3424(\mathrm{OH}), 2905(\mathrm{CH}), 987,920,896$, 848 (intensity $920>896,(25 S)$-spiroketal) $\mathrm{cm}^{-1} ;{ }^{1} \mathrm{H}-\mathrm{NMR}$ (pyridine- $d_{5}, 500 \mathrm{MHz}$ ) data and ${ }^{13} \mathrm{C}-\mathrm{NMR}$ (pyridine- $d_{5}, 300 \mathrm{MHz}$ ) data: see Tables 1-4; ESI-MS $m / z$ 909 [M + Na $]^{+}$; HRESI-QTOF-MS $m / z$ 909.4456 [M + Na $]^{+}$(calcd for $\mathrm{C}_{44} \mathrm{H}_{70} \mathrm{O}_{18} \mathrm{Na}, 909.4454$ ).

Compound 2. White amorphous powder; $[\alpha]_{23}^{\mathrm{D}}-56.27$ (c 0.10, MeOH); IR (KBr) $\nu_{\max }: 3476(\mathrm{OH}), 2950(\mathrm{CH}), 982,921,902$, 870 (intensity $902>$ 921, (25R)-spiroketal) $\mathrm{cm}^{-1} ;{ }^{1} \mathrm{H}-\mathrm{NMR}$ (pyridine- $d_{5}, 500 \mathrm{MHz}$ ) data and ${ }^{13} \mathrm{C}-\mathrm{NMR}$ (pyridine- $d_{5}, 300$ MHz) data: see Tables 1-4; ESI-MS $m / z 909$ [M + Na $]^{+}$; HRESIQTOF-MS $m / z$ 909.4454 $[\mathrm{M}+\mathrm{Na}]^{+}$(calcd for $\mathrm{C}_{44} \mathrm{H}_{70} \mathrm{O}_{18} \mathrm{Na}$, 909.4454).

Compound 3. White amorphous powder; $[\alpha]_{23}^{\mathrm{D}}-43.48$ (c 0.10, MeOH); IR (KBr) $\nu_{\text {max }} 3441(\mathrm{OH}), 2905(\mathrm{CH}), 987,920,896$, 848 (intensity $920>896,(25 S)$-spiroketal) $\mathrm{cm}^{-1}$; ${ }^{1} \mathrm{H}-\mathrm{NMR}$ (pyridine- $d_{5}, 500 \mathrm{MHz}$ ) data and ${ }^{13} \mathrm{C}-\mathrm{NMR}$ (pyridine- $d_{5}, 300 \mathrm{MHz}$ ) data: see Tables 1-4; ESI-MS $m / z$ 879 [M + Na $]^{+}$; HRESI-QTOF-MS $m / z$ 879.4344 [M $+\mathrm{Na}]^{+}$(calcd for $\mathrm{C}_{43} \mathrm{H}_{68} \mathrm{O}_{17} \mathrm{Na}, 879.4349$ ).

Compound 4. White amorphous powder; $[\alpha]_{23}^{\mathrm{D}}-59.73$ (c 0.10, MeOH); IR (KBr) $\nu_{\max }: 3449(\mathrm{OH}), 2950(\mathrm{CH}), 982,921,902$, 870 (intensity $902>$ 921, (25R)-spiroketal) $\mathrm{cm}^{-1} ;{ }^{1} \mathrm{H}-\mathrm{NMR}$ (pyridine- $d_{5}, 500 \mathrm{MHz}$ ) data and ${ }^{13} \mathrm{C}-\mathrm{NMR}$ (pyridine- $d_{5}, 300$ MHz) data: see Tables 1-4; ESI-MS $m / z 879$ [M + Na $]^{+}$; HRESIQTOF-MS $m / z$ 879.4372 $[\mathrm{M}+\mathrm{Na}]^{+}$(calcd for $\mathrm{C}_{43} \mathrm{H}_{68} \mathrm{O}_{17} \mathrm{Na}$, 879.4349).

Compound 5. White amorphous powder; $[\alpha]_{23}^{\mathrm{D}}-67.28$ (c 0.10, MeOH); IR (KBr) $\nu_{\text {max }} 3416(\mathrm{OH}), 2903(\mathrm{CH}), 984,920,900$, 865 (intensity $900>920$, (25R)-spiroketal) $\mathrm{cm}^{-1} ;{ }^{1} \mathrm{H}-\mathrm{NMR}$ (pyridine- $d_{5}, 500 \mathrm{MHz}$ ) data and ${ }^{13} \mathrm{C}-\mathrm{NMR}$ (pyridine- $d_{5}, 300$ MHz) data: see Tables 1-4; ESI-MS $m / z 893[\mathrm{M}+\mathrm{Na}]^{+}$; HRESIQTOF-MS $m / z$ 871.4702 $[\mathrm{M}+\mathrm{H}]^{+}$(calcd for $\mathrm{C}_{44} \mathrm{H}_{70} \mathrm{O}_{17} \mathrm{Na}$, 871.4686).

Compound 6. White amorphous powder; $[\alpha]_{23}^{\mathrm{D}}-55.86$ (c 0.10, MeOH); IR (KBr) $\nu_{\max }: 3424(\mathrm{OH}), 2905(\mathrm{CH}), 987,920,896$, 848 (intensity $920>896,(25 S)$-spiroketal) $\mathrm{cm}^{-1}$; ${ }^{1} \mathrm{H}-\mathrm{NMR}$ (pyridine- $d_{5}, 500 \mathrm{MHz}$ ) data and ${ }^{13} \mathrm{C}-\mathrm{NMR}$ (pyridine- $d_{5}, 300 \mathrm{MHz}$ ) data: see Tables 1-4; ESI-MS $m / z 893$ [M + Na] ${ }^{+}$; HRESI-QTOF-MS $m / z$ 893.4461 [M $+\mathrm{Na}]^{+}$(calcd for $\mathrm{C}_{44} \mathrm{H}_{70} \mathrm{O}_{17} \mathrm{Na}, 893.4505$ ).

Compound 7. White amorphous powder; $[\alpha]_{23}^{\mathrm{D}}-67.59$ (c 0.10, $\mathrm{MeOH})$; IR (KBr) $\nu_{\text {max }}: 3385(\mathrm{OH}), 2907(\mathrm{CH})$, 982, 920, 900, 864 (intensity $900>920,(25 R)$-spiroketal) $\mathrm{cm}^{-1} ;{ }^{1} \mathrm{H}$-NMR (pyridine$d_{5}, 500 \mathrm{MHz}$ ) data and ${ }^{13} \mathrm{C}-\mathrm{NMR}$ (pyridine- $d_{5}, 300 \mathrm{MHz}$ ) data: see Tables 1-4; ESI-MS $m / z 893[\mathrm{M}+\mathrm{Na}]^{+}$; HRESI-QTOF-MS $\mathrm{m} / \mathrm{z}$ 893.4462 [M + Na $]^{+}$(calcd for $\mathrm{C}_{44} \mathrm{H}_{70} \mathrm{O}_{17} \mathrm{Na}, 893.4505$ ).

Compound 8. White amorphous powder; $[\alpha]_{23} \mathrm{D}-65.48$ (c 0.10, MeOH); IR (KBr) $\nu_{\max }: 3452(\mathrm{OH}), 2944,2844,1064(\mathrm{CH})$, 1048, 983, 922, 895, $838 \mathrm{~cm}^{-1}$; ${ }^{1} \mathrm{H}-\mathrm{NMR}$ (pyridine- $d_{5}, 500 \mathrm{MHz}$ ) data and ${ }^{13} \mathrm{C}-\mathrm{NMR}$ (pyridine- $d_{5}, 300 \mathrm{MHz}$ ) data: see Tables 1-4; ESI-MS $m / z 877[\mathrm{M}+\mathrm{Na}]^{+}$; HRESI-QTOF-MS $m / z$ 877.4189 [M + $\mathrm{Na}]^{+}$(calcd for $\mathrm{C}_{43} \mathrm{H}_{66} \mathrm{O}_{17} \mathrm{Na}$, 877.4192).

Compound 9. White amorphous powder; $[\alpha]_{23}^{\mathrm{D}}-60.83$ (c 0.10, MeOH); IR (KBr) $\nu_{\text {max }} 3443(\mathrm{OH}), 2937,2849,1062(\mathrm{CH})$, 1049, 985, 922, 901, $843 \mathrm{~cm}^{-1}$; ${ }^{1} \mathrm{H}-\mathrm{NMR}$ (pyridine- $d_{5}, 500 \mathrm{MHz}$ ) data and ${ }^{13} \mathrm{C}-\mathrm{NMR}$ (pyridine- $d_{5}, 300 \mathrm{MHz}$ ) data: see Tables 1-4; 
ESI-MS $m / z 891[\mathrm{M}+\mathrm{Na}]^{+}$; HRESI-QTOF-MS $m / z$ 869.4529 [M + $\mathrm{H}]^{+}$(calcd for $\mathrm{C}_{44} \mathrm{H}_{69} \mathrm{O}_{17}, 869.4529$ ).

Compound 10. White amorphous powder; $[\alpha]_{23}^{\mathrm{D}}-57.71$ (c 0.10, MeOH); IR (KBr) $\nu_{\text {max }}: 3441(\mathrm{OH}), 2937,2849,1062(\mathrm{CH})$, 1049, 985, 922, 901, $844 \mathrm{~cm}^{-1}$; ${ }^{1} \mathrm{H}-\mathrm{NMR}$ (pyridine- $d_{5}, 500 \mathrm{MHz}$ ) data and ${ }^{13} \mathrm{C}-\mathrm{NMR}$ (pyridine- $d_{5}, 300 \mathrm{MHz}$ ) data: see Tables 1-4; ESI-MS $m / z 891[\mathrm{M}+\mathrm{Na}]^{+}$; HRESI-QTOF-MS $m / z$ 891.4320 [M + $\mathrm{Na}]^{+}$(calcd for $\mathrm{C}_{44} \mathrm{H}_{68} \mathrm{O}_{17} \mathrm{Na}, 891.4349$ ).

\section{Acid hydrolysis of compounds 1-10}

Each compound $(2 \mathrm{mg}$ ) was refluxed with $2 \mathrm{~mL}$ of $2 \mathrm{M} \mathrm{HCl}$ (dioxane- $\mathrm{H}_{2} \mathrm{O}, 1: 1$ ) at $100{ }^{\circ} \mathrm{C}$ for $4 \mathrm{~h}$. The solution was diluted with $\mathrm{H}_{2} \mathrm{O}(2 \mathrm{~mL})$ and extracted with EtOAc $(1 \mathrm{~mL} \times 3)$ after the removal of dioxane. The aqueous layer was evaporated under vacuum, and the residue was diluted with $\mathrm{H}_{2} \mathrm{O}(50 \mathrm{~mL})$. This procedure was repeated until a neutral residue was obtained (10-15 times), and then it was analyzed by TLC over silica gel $\left(\mathrm{Me}_{2} \mathrm{CO}-n-\mathrm{BuOH}-\mathrm{H}_{2} \mathrm{O}, 6: 3: 1\right)$ together with authentic sugar samples. The remaining residue was dissolved in pyridine $(300$ $\mu \mathrm{L}$ ), and L-cysteine methyl ester hydrochloride ( $4 \mathrm{mg}$ ) was added to it. The mixture was kept at $60^{\circ} \mathrm{C}$ in an oil bath for $1.5 \mathrm{~h}$. Then $300 \mu \mathrm{L}$ of hexamethyldisilazane-trimethylchlorosilane $(2: 1)$ was added and the mixture was heated at $60{ }^{\circ} \mathrm{C}$ in an oil bath for a further $30 \mathrm{~min}$. After centrifugation, the supernatant was analyzed by GC under the following conditions: capillary column, HP-5 $(0.32 \mathrm{~mm} \times 30 \mathrm{~m} \times 0.5 \mu \mathrm{m})$; flame ionization detection; detector temperature, $280{ }^{\circ} \mathrm{C}$; injection temperature, $250{ }^{\circ} \mathrm{C}$; initial temperature, $200{ }^{\circ} \mathrm{C}$ and an initial time of $8 \mathrm{~min}$, $6{ }^{\circ} \mathrm{C} \min ^{-1}$ to $260{ }^{\circ} \mathrm{C}$ and then held for $2 \mathrm{~min}$; carrier, $\mathrm{N}_{2}$; split ratio, $1 / 50$. The monosaccharides present in compounds $\mathbf{1}, \mathbf{2}, \mathbf{3}$, $\mathbf{4}$ and $\mathbf{8}$ were confirmed to be D-glucose and D-xylose by comparing the retention times $\left(T_{\mathrm{R}}\right)$ of monosaccharide derivatives with the derivatives prepared similarly from standard sugars. In the same procedure, D-glucose, L-rhamnose and Dxylose were identified from compounds 6 and 7, D-glucose, Larabinose and D-fucose for compound 5, and D-glucose, D-xylose and D-fucose from compound $\mathbf{1 0 .}$

\section{Cytotoxicity assay}

Cell lines and culture. MDA-MB-435, 95D, HepG2, HeLa, MCF-7 and A549 cells were obtained from the Cell Bank of the Shanghai Institute of Chinese Academy of Sciences and cultured with high glucose DMEM medium or RPMI 1640 medium basic (Gibco, Grand Island, NY, USA) supplemented with $10 \%$ fetal bovine serum (Life Technologies Corporation, Carlsbad, CA, USA). All cells were maintained in the logarithmic phase under a humidified atmosphere of $95 \%$ air and $5 \% \mathrm{CO}_{2}$ at $37{ }^{\circ} \mathrm{C}$.

MTT assay. Cell viability was determined by the $3-(4,5-$ dimethylthiazol-2-yl)-2,5-diphenyltetrazolium bromide (MTT) method as described in the literature. ${ }^{7}$ The cells were seeded in 96-well plates at a density of $1 \times 10^{4}$ cells with $100 \mu \mathrm{L}$ culture medium per well for $12 \mathrm{~h}$. Aliquots of fresh medium $(100 \mu \mathrm{L})$ containing test compounds $(0-100 \mu \mathrm{M})$ were added to each well. The medium was removed after an additional $48 \mathrm{~h}$ of cultivation in a humidified atmosphere of $95 \%$ air and $5 \% \mathrm{CO}_{2}$ at $37{ }^{\circ} \mathrm{C}$. An aliquot $(100 \mu \mathrm{L})$ of fresh medium containing $0.5 \mathrm{mg} \mathrm{mL}^{-1} \mathrm{MTT}$ was added to the plate, and the cells were cultured for an additional $3 \mathrm{~h}$. The medium solution was then removed, and an aliquot of DMSO $(150 \mu \mathrm{L})$ added to the plate. The optical density of the formazan solution was analyzed by detection of the absorbance at $570 \mathrm{~nm}$ and reference wavelength of $650 \mathrm{~nm}$ on a microplate reader.

\section{Conclusions}

In this work, ten new steroidal saponins (1-10) and three known steroidal saponins (11-13) were isolated from the root of $L$. muscari. Their structures were determined using IR, NMR and mass spectroscopic data. These compounds exhibited different cytotoxic activity against six cancer cell lines in vitro. Structureactivity analysis of these related compounds revealed that the $\mathrm{C}$ 25 configuration of the aglycone moiety and the sugar chain may together determine the cytotoxicity of steroidal saponins. These results provide a basis for evaluating the structureactivity relationships of other steroidal saponins, as well as for developing these compounds as potential anticancer drugs.

\section{Acknowledgements}

This project was financially supported by the National Natural Science Foundation of China (No. 81473317 and 81673555), the Major National Science and Technology Project of China for Significant New Drugs Development (No. 2012ZX09102201-015), Qing Lan Project, the Priority Academic Program Development of Jiangsu Higher Education Institutions, the 2011 Program for Excellent Scientific and Technological Innovation Team of Jiangsu Higher Education, and the Major Project Program of State Key Laboratory of Natural Medicines, China Pharmaceutical University (No. SKLNMZZ201203).

\section{Notes and references}

1 B. Y. Yu, G. J. Xu and R. L. Jin, J. China Pharm. Univ., 1991, 3, 150-153.

2 X. C. Fang, B. Y. Yu, B. R. Xiang and D. K. An, J. Chromatogr. A, 1990, 514, 287-292.

3 B. Y. Yu and G. J. Xu, Chin. Tradit. Herb. Drugs, 1995, 26, 205210.

4 B. Y. Yu, Chin. J. Nat. Med., 2007, 1, 10-14.

5 China Pharmacopoeia Committee, P. Chinese Pharmacopoeia, Chemical Industry Press, 2010.

6 ed. Pharmacopoeia Commission of PRC, Pharmacopoeia of the People's Republic of China, China Medical Science Press, 2010.

7 Y. W. Li, J. Qi, Y. Y. Zhang, Z. Huang, J. P. Kou, S. P. Zhou, Y. Zhang and B. Y. Yu, Chin. J. Nat. Med., 2015, 13, 461-466.

8 Y. Tian, S. Ma, B. Lin, J. Kou and B. Yu, Indian J. Pharmacol., 2013, 45, 283-285.

9 Y. Q. Tian, J. P. Kou, L. Z. LI and B. Y. YU, Chin. J. Nat. Med., 2011, 9, 222-226.

10 Q. Xu, R. Wang and B. Y. Yu, J. China Pharm. Univ., 1993, 24, 98-101. 
11 J. Liu, T. Chen, B. Yu and Q. Xu, J. Pharm. Pharmacol., 2002, 54, 959-965.

12 J. Song, J. Kou, Y. Huang and B. Yu, J. Pharmacol. Sci., 2010, 113, 409-413.

13 C. Qiu, L. Jozsef, B. Yu and J. Yu, Biochem. Biophys. Res. Commun., 2014, 443, 74-79.

14 J. Tao, H. Wang, H. Zhou and S. Li, Life Sci., 2005, 77, 30213030.

15 S. Man, W. Gao, Y. Zhang, L. Huang and C. Liu, Fitoterapia, 2010, 81, 703-714.

16 S. G. Sparg, M. E. Light and J. V. Staden, J. Ethnopharmacol., 2004, 94, 219-243.

17 A. V. Rao and D. M. Gurfinkel, Drug Metab. Drug Interact., 2000, 17(1-4), 211-235.

18 J. L. Liu, T. Chen, B. Y. Yu and Q. XU, J. Pharm. Pharmacol., 2002, 54, 959-966.

19 J. Tao, H. Wang, J. Chen, H. Xu and S. Li, Am. J. Chin. Med., 2005, 33, 797-806.

20 L. Sun, S. Lin, R. Zhao, B. Yu, S. Yuan and L. Zhang, Biol. Pharm. Bull., 2010, 33, 1192-1198.

21 Y. Zhang, J. Liu, J. Kou, J. Yu and B. Yu, Mol. Med. Rep., 2012, 6, 1121-1125.

22 L. Sun, S. S. Lin, B. Y. Yu, S. T. Yuan and L. Y. Zhang, Chin. J. Nat. Med., 2010, 8, 466-470.

23 Y. Y. Zhang, J. H. Liu, J. P. Kou, J. Yu and B. Y. Yu, Chin. J. Nat. Med., 2012, 10, 436-440.

24 R. P. Zhao, S. S. Lin, S. T. Yuan, B. Y. Yu, X. S. Bai, L. Sun and L. Y. Zhang, Chin. J. Nat. Med., 2014, 12, 24-29.

25 S. S. Lin, W. Fan, L. Sun, F. F. Li, R. P. Zhao, L. Y. Zhang, B. Y. Yu and S. T. Yuan, Chin. J. Nat. Med., 2014, 12, 833-840.

26 H. Li, L. Sun, E. L. de Carvalho, X. Li, X. Lv, G. J. Khan, H. Semukunzi, S. Yuan and S. Lin, Eur. J. Pharmacol., 2016, 781, 164-172.
27 X. W. Yu, S. Lin, H. Z. Du, R. P. Zhao, S. Y. Feng, B. Y. Yu, L. Y. Zhang, R. M. Li, C. M. Qian, X. J. Luo, S. T. Yuan and L. Sun, Oncotarget, 2016, 7, 32990-33003.

28 S. Ma, J. Kou and B. Yu, Food Chem. Toxicol., 2011, 49, 22432251.

29 L. L. Chen, W. W. Yuan, Z. F. Hu, J. Qi, D. N. Zhu and B. Y. Yu, J. Pharm. Biomed. Anal., 2011, 56, 650-654.

30 B. Y. Yu, Y. Hirai, J. Shoji and G. J. Xu, Chem. Pharm. Bull., 1990, 38, 1931-1935.

31 B. Y. Yu, S. X. Qiu, K. Zaw, G. J. Xu, Y. Hirai, J. Shoji, H. H. Fong and A. D. Kinghorn, Phytochemistry, 1996, 43, 201-206.

32 D. Y. Lee, K. H. Son, J. C. Do and S. S. Kang, Arch. Pharmacal Res., 1989, 12, 295-299.

33 Z. H. Cheng, T. Wu, Y. L. Guo, B. Y. Yu and S. X. Luo, Chin. Chem. Lett., 2006, 17, 31-34.

34 L. Jin, Y. Zhang, L. Yan, Y. Guo and L. Niu, Molecules, 2012, 17, 1797-1808.

35 C. Jiang, Z. H. Liu, L. Li, B. B. Lin, F. Yang and M. J. Qin, J. Asian Nat. Prod. Res., 2012, 14, 491-495.

36 P. K. Agrawal, D. C. Jain and A. K. Pathak, Magn. Reson. Chem., 1995, 33, 923-953.

37 Y. Mimaki, Y. Takaashi, M. Kuroda, Y. Sashida and T. Nikaido, Phytochemistry, 1996, 42, 1609-1615.

38 C. L. Sun, W. Ni, H. Yan, Z. H. Liu, L. Yang, Y. A. Si, Y. Hua, C. X. Chen, L. He, J. H. Zhao and H. Y. Liu, Steroids, 2014, 92, 90-95.

39 L. P. Kang, Y. X. Liu, T. Eichhorn, E. Dapat, H. S. Yu, Y. Zhao, C. Q. Xiong, C. Liu, T. Efferth and B. P. Ma, J. Nat. Prod., 2012, 75, 1201-1205.

40 H. Y. Shen, W. J. Zuo, H. Wang, Y. X. Zhao, Z. K. Guo, Y. Luo, X. N. Li, H. F. Dai and W. L. Mei, Fitoterapia, 2014, 94, 94101. 